\title{
O Estado brasileiro sob Bolsonaro
}

\author{
neoliberalismo, neofacismo e fundamentalismo
}

\author{
Wagner Pires da Silva \\ Universidade Federal de Pelotas \\ Erlene Pereira Barbosa \\ Universidade Federal do Ceará
}

Resumo: Eleito em 2018, após manobras jurídicas que impediram a candidatura de Lula da Silva, líder nas pesquisas, Bolsonaro, levou ao governo não apenas uma política econômica neoliberal, mas o interesse de diversos grupos que o apoiaram durante a campanha eleitoral. A guinada conservadora somada ao corte de programas sociais, as reformas que retiram direitos da população e a grave pandemia do COVID-19, refletiram na baixa popularidade, mas ainda há apoiadores fiéis ao presidente e ao seu projeto. Este trabalho analisa a ascensão do bolsonarismo e a persistência desses apoios, no momento em que é cada vez maior a insatisfação com o governo.

Palavras-chave: Bolsonarismo; neoliberalismo; Extrema-direita; Estado; COVID-19.

Abstract: Elected in 2018, after legal maneuvers that prevented the candidacy of Lula da Silva, leader in polls, Bolsonaro, took to the government not only a neoliberal economic policy, but the interest of several groups that supported him during the electoral campaign. The conservative shift added to the cut in social programs, the reforms that remove rights from the population and the serious pandemic of COVID-19, reflected in the low popularity, but there are still loyal supporters of the president and his project. This paper analyzes the rise of the pocketbook and the persistence of these supports, at a time when dissatisfaction with the government is growing.

Keywords: Bolsonarism; neoliberalismo; Far right; State; COVID-19.

\section{INRODUÇÃO}

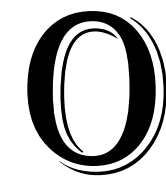

Estado é uma construção histórico-social dos homens, como tal, ele reflete as relações entre estes. Para Marx o Estado é uma ferramenta da classe dominante para manter o status quo e garantir que as demais classes permaneçam subjugadas. Nas primeiras décadas do século XXI, o Estado brasileiro foi identificado como motor de mudanças nas relações de trabalho e como indutor de 
melhorias para as classes menos favorecidas, ao mesmo tempo em que se buscava diminuir as desigualdades sociais por meio de diversas políticas públicas.

Essa visão começa a ser questionada e as pressões pela diminuição do Estado, com apelo a privatizações e a concessões à iniciativa privada se tornam mais comum. Ao mesmo tempo, uma onda conservadora ganha espaço, identificando as políticas de inclusão social e de gênero como nocivas a seus valores e a seu modo de vida. $\mathrm{O}$ aumento da percepção da violência e a presunção de que os governos de esquerda são lenientes para o assunto pela ênfase que estes fazem da defesa dos direitos humanos deu uma conformação peculiar a uma parte da sociedade brasileira, que exprime sua insatisfação e desalento votando no candidato que reunia ao seu redor os principais grupos que empunhavam as bandeiras do Estado Mínimo, da reação conservadora e do combate à violência: Jair Bolsonaro. Parlamentar desde a década de 1990, mas pouco conhecido fora do seu reduto eleitoral (o Rio de Janeiro), Bolsonaro projetou ainda, ao restante do país a figura de representante da Nova Política, que se levantava contra as práticas da velha política. O presente artigo é uma análise do Bolsonarismo, movimento político criado ao redor do presidente e que tem demonstrado vitalidade, no momento em que a CPI da COVID-19 tem apresentado cada vez mais denúncias da inação do presidente diante da pandemia, bem como o envolvimento de ministros e auxiliares em irregularidades na compra de vacinas.

\section{Ascensão do neoliberalismo e seus valores}

A partir dos anos 1980, o neoliberalismo, onde quer que tenha chegado ao poder, inicia a implementação de um novo sistema de normas, no qual a lógica da concorrência se estende a toda a sociedade (DARDOT; LAVAL, 2017). Pode-se dizer que "os mercados - e os valores de mercado - passaram a governar a nossa vida como nunca" (SANDEL, 2012, p.11). O mercado se utiliza do individualismo para se retroalimentar indefinidamente "por meio de operações ideológicas que inculcam como dever moral satisfazer as preferências individuais, que são induzidas pelo próprio mercado" (CHAUÍ, 2013, p.89).

Embora a crise de 2008, tenha demonstrado que um mercado livre das amarras e da supervisão estatal tem consequências desastrosas, o discurso, segundo o qual o mercado seria mais eficiente que o Estado, se manteve. Os governos tiveram que esforçarse para salvar o mercado, por meio do aporte de milhões de dólares, para logo depois, serem tachados como gastadores irresponsáveis pelos neoliberais (BLYTH, 2017). 
No Brasil, onde houve uma considerável expansão dos serviços públicos, durante o governo do Partido dos Trabalhadores, a lógica neoliberal teve sucesso em ligar a recessão, agravada a partir de 2015, a uma suposta ineficiência do Estado, que, mesmo com uma alta carga tributária, não conseguia atender às necessidades da população. $\mathrm{O}$ receituário neoliberal pregava a diminuição do Estado, estimulando o repasse à iniciativa privada de uma série de atividades estatais, sob a alegação de que estas seriam ofertadas com mais eficiência. Por outro lado, a consequente diminuição da carga tributária possibilitaria ao setor privado ampliar os investimentos, gerando mais empregos e renda.

Para tanto, as medidas neoliberais precisam construir "um imaginário social que busca justificá-las (como racionais), legitimá-las (como corretas) e dissimulá-las (como formas contemporâneas da exploração e da dominação) " (CHAUí, 2001, p.21). Para convencer a população, da necessidade do Estado Mínimo, uma intensa campanha veiculada pela grande mídia, buscou associar uma série de direitos dos brasileiros como privilégios que, longe de beneficiarem a todos, geravam uma elite de funcionários públicos bem remunerados e pouco eficientes, bem como uma casta de políticos corruptos. Em contrapartida, o mercado ofertaria saúde, educação, previdência social e outras ações não apenas melhor que o Estado, mas, graças aos mecanismos de concorrência do livre mercado, a preços acessíveis a toda a população.

Somado a isso estimulava-se uma ética e uma moral individualista, que prega o indivíduo como responsável por seu sucesso ou fracasso, seja por meio das narrativas apresentadas nos programas de TV, como os reality shows, seja em postagens nas mídias sociais. O objetivo era consolidar que a sociedade deve ser vista como o espaço, por excelência, da propriedade privada, onde "a razão da existência pessoal deixa de ser a articulação com a vida coletiva, para ser o mero enriquecimento privado" (LESSA; TONET, 2011, p. 78).

Outra estratégia de desqualificação do Estado frente o Mercado foi forçar a identificação da atuação estatal com os totalitarismos do século passado. Nestes regimes, a busca pelo poder e pela manutenção deste levaram a relativização da importância do indivíduo, retirando deste direitos e garantias básicas (MARTINS, 2015). Com este pano de fundo, opera-se, em nome da defesa do indivíduo, o fim dos direitos, como forma de garantir a liberdade de escolha.

O neoliberalismo, na busca pela implementação de sua agenda não hesita golpear até mesmo a democracia liberal, uma vez que a democracia é inseparável da ideia de espaço público (CHAUÍ, 2001). Este é suprimido diante da ampliação da esfera privada 
e do individualismo, necessários para a ascensão do neoliberalismo, enquanto agenda diretiva da atuação do Estado.

Dardot e Laval (2016) afirmam que o atual neoliberalismo está muito longe do liberalismo laissez-faire. Neste caberia ao governo orientar, estimular e combinar os interesses individuais no serviço do bem comum. Já o atual neoliberalismo pretende simplesmente exacerbar o Estado enquanto escritório de negócios da burguesia, como escreveram Marx e Engels (2015). O neoliberalismo busca

(...) fazer do mercado tanto o princípio do governo dos homens como o do governo de si (...). Considerado uma racionalidade governamental, e não uma doutrina mais ou menos heteróclita, o neoliberalismo é precisamente o desenvolvimento da lógica do mercado como lógica normativa generalizada, desde o Estado até o mais íntimo da subjetividade (DARDOT; LAVAL, 2016, p.34).

O que desejam os neoliberais não é a pura diminuição do Estado e ampliação do Mercado, mas a captura do Estado para o melhor interesse do Mercado. O congresso brasileiro, eleito em 2018, junto com Bolsonaro, conta com diversos líderes de movimentos de direita, ligados a think tanks neoliberais. Estes também ocupam diversos cargos em várias esferas do governo, nos mais diversos níveis, ampliando a retirada de direitos "em nome de projetos e ideais que valorizam apenas os indivíduos e grupos significativos para a estrutura econômica" (MARTINS, 2015, p.79).

A ofensiva ideológica se reflete em alterações na gestão pública, tanto pelos dispositivos legais aprovados pelo congresso, quanto pelos normativos editados pelo executivo. São nítidas as pressões para que a gestão pública atue conforme o modelo de gestão das empresas privadas.

Essa modificação da atuação e da elaboração das políticas públicas, acredita Sandel (2012) mostra que o mercado e seus valores acabaram por perpassar toda a vida social atual, levando a a uma sociedade bem peculiar, que já não teria uma economia de mercado, ela própria seria uma sociedade de mercado.

A diferença é esta: uma economia de mercado é uma ferramenta - valiosa e eficaz - de organização de uma atividade produtiva. Uma sociedade de mercado é um modo de vida em que os valores de mercado permeiam cada aspecto da atividade humana. É um lugar em que as relações sociais são reformatadas à imagem do mercado (SANDEL, 2012, p.16)

O mercado possuiria expectativas a serem atendidas pelo indivíduo, cabendo a este qualificar-se para atender a essas expectativas, utilizando seus próprios recursos, garantido seu sucesso na nova sociedade de mercado. Esta é, em resumo, a teoria do capital humano, que vê a qualificação como um empreendimento a ser assumido individualmente. 
...essa "teoria" implica à subjetividade que trabalha, forjar uma concepção de si como "empreendedor/a" que investe na sua força de trabalho como se ela não fosse uma mercadoria, mas parte de um negócio próprio cuja venda lhe retorna um "capital". Ser um "empreendedor/a" nesse sentido, é dispor-se a gerencia a própria vida analogamente à gestão de uma empresa, como um “empreendedor/a" capitalista (ANTUNES; PINTO, 2017, p.102).

A divisão do trabalho entre o trabalho material e imaterial não é nenhuma novidade, o que é novo nessa sociedade de mercado é a responsabilização individual tanto para a aquisição dos conhecimentos quanto para o custeio da mesma. Dessa forma as desigualdades sociais da sociedade seriam problemas individuais. A sociedade ficaria dividida entre os que possuem o direito de comandar, por serem possuidores dos conhecimentos técnicos e científicos conquistado por mérito próprio, sendo, portanto, competentes e os incompetentes, assim considerados por não terem os conhecimentos considerados necessários, tendo que obrigatoriamente subordinarem-se aos primeiros (CHAUÍ, 2013).

A tecnologia, que poderia liberar a humanidade para a realização de atividades que expressassem a omnilateralidade de mulheres e homens, acaba, ao ser apropriado pelo capital apenas para extração de mais-valor, "convertendo-se em sujeito, num processo avassalador que termina por capturar a humanidade e, em vez de alforriá-la, submete-a à maior das servidões" (DOMINGUES, 2016, p.34).

É sobre este pano de fundo que foi pavimentado o caminho de Bolsonaro ao controle do Estado. Antes de analisar o que é o bolsonarismo e o que ele representa, a forma como ele desmonta o desmonta o Estado e a própria democracia brasileira, o trabalho irá realizar algumas consideração sobre o Estado e a democracia burguesa.

\section{A questão do Estado em Marx e Lênin}

Em sua juventude, Marx abordara o Estado em outras obras e seu ponto de vista sobre o mesmo era muito próximo de Hegel. Assim, ele considerava o Estado uma deturpação burocrática. A partir da publicação de A Ideologia Alemã, ele apresenta o Estado como aparelho de dominação de uma classe sobre a outra. Este salto de compreensão segue a obra do autor, que embora tenha projetado abordar mais detidamente essa questão, acabou não escrevendo mais diretamente sobre isso.

Os homens começam a se diferenciar dos outros animais quando começam a produzir a sua existência, pois, "ao produzirem a sua existência, os homens produzem imediatamente a sua vida material” (MARX e ENGELS, 2006, p. 44). Essa produção da 
vida material, continuam os autores, acaba por estabelecer entre os homens relações sociais e políticas determinadas. Dessas relações nasce o Estado:

\begin{abstract}
A estrutura social e o Estado nascem continuamente do processo vital de indivíduos determinados, porém esses indivíduos não podem parecer à imaginação própria ou dos outros, mas tal e qual realmente são, isto é, tal como atuam e produzem materialmente e, portanto, tal como desenvolvem suas atividades sob determinadas limitações, pressupostos e condições materiais independentemente de sua vontade (MARX e ENGELS, 2006, p. 50-51).
\end{abstract}

Em outras palavras, mesmo a produção de ideias, representações e da consciência, provêm da atividade material humana, sendo determinadas por elas, o que leva ao fato de que as ideias dominantes em determinada sociedade são as da classe dominante dessa sociedade, uma vez que, "a classe que dispõe dos meios de produção material também dispõe dos meios de produção espiritual” (MARX e ENGELS, 2006, p.78).

Controlando a produção espiritual, a burguesia pôde formular e moldar a sua concepção de Estado, o qual segundo Marx é necessária, porque como classe, a burguesia precisa de uma organização nacional para que seus interesses possam ter uma forma universal, dando ao Estado uma existência particular, fora da sociedade civil, no entanto “tal Estado não é mais do que a forma de organização que os burgueses adotam, tanto para garantir reciprocamente a sua propriedade e a de seus interesses tanto em seu interior, quanto externamente" (MARX e ENGELS, 2006, p. 98). Para os autores, sendo o Estado uma forma pela qual a classe dominante faz valer seus direitos, então, as instituições, que recebem delem sua forma política, se prestam ao mesmo papel, pois as classes dominantes, afirma Engels (2014, p. 300-301) "mantêm a população trabalhadora na servidão não só mediante o poder de sua riqueza, pela simples exploração do trabalho pelo capital, mas também pelo poder do Estado - pelo exército, pela burocracia, pelos tribunais".

Esse Estado, segundo Mascaro (2015, p. 24) "não é ocasionalmente capitalista, e sim necessariamente capitalista". A forma de organização estatal é específica do capitalismo, estando a serviço da manutenção do sistema. Depreende-se isso do fato que "as relações sociais estão intimamente ligadas às forças produtivas. Adquirindo as novas forças produtivas, os homens mudam o seu modo de produção, e mudando o modo de produção, a maneira de ganhar a vida, mudam todas as suas relações sociais" (MARX, 2008, p. 135). Ou seja, o Estado, em sua configuração atual, não existia durante o 
feudalismo, ou durante o modo de produção escravista, mas foi constituído, como observado, pela burguesia para consolidar e defender seu domínio sobre a sociedade. Para a burguesia o Estado seria "uma organização política, administrativa e jurídica que se constitui com a existência de um povo em um território fixo e submetido a uma soberania" (SILVA; BASSI, 2012, p. 16). Como observado até aqui, essa soberania é exercida por meio dos governos, que exercem a gestão da coisa pública, seguindo os preceitos do sistema capitalista, uma vez que

(...) o Estado revela-se principalmente um vasto aparelho administrativo, de tal forma que os governantes se mostram como funcionários recitando principalmente diretrizes de cunho econômico-financeiras, em geral de acordo com as orientações ou injunções de corporações transnacionais e organizações multilaterais (IANNI, 2004, p. 51)

O Estado deve ser destruído, pois uma simples substituição da classe no governo não seria suficiente para garantir o fim das opressões. Quando Marx fala sobre a substituição da antiga sociedade civil e de não haver mais poder político propriamente dito, ele faz referência ao fato de que "a classe operária não pode simplesmente de apossar da máquina estatal tal como ela se apresenta e dela servir-se para fins próprios" (MARX, 2014, p. 235). Como dito acima, o Estado foi moldado de acordo com as necessidades da burguesia. É preciso que ele seja modificado para atender as necessidades proletárias, pois "a dominação política dos produtores não pode coexistir com a perpetuação da sua escravidão social” (MARX, 2014, p. 241). E esta tarefa, continua, Marx, não é algo simples, os trabalhadores,

\footnotetext{
Sabem, que para atingir sua própria emancipação e, com ela, essa forma superior de vida para a qual a sociedade atual, por seu próprio desenvolvimento econômico, tende irresistivelmente, terão de passar por longas lutas, por uma série de processos históricos que transformarão as circunstâncias e os homens. Eles não têm nenhum ideal a realizar, mas querem libertar os elementos da nova sociedade dos quais a velha e agonizante sociedade burguesa está grávida (MARX, 2014, p. 242).
}

Baseando-se em Marx, Lênin deixa claro, que "a revolução deve consistir não em que a nova classe comande e administre com a ajuda da velha máquina de Estado, mas que ela quebre essa máquina e comande administre, com a ajuda de uma máquina nova" (LÊNIN, 2017, p.142).

Marx em sua obra apresentou as disputas entre as diversas classes sociais e grupos políticos da França pelo poder do Estado. Relata a situação de cada grupamento político, suas posturas e estratégias, bem como as suas alianças em defesa dos interesses das 
classes que representavam, fazendo a ressalva de que "nas lutas históricas deve-se distinguir mais ainda as frases e as fantasias dos partidos de sua formação real e de seus interesses reais, o conceito que fazem de si do que são na realidade” (MARX, 1988, p.27).

Apresenta como disputa principal a existente entre a burguesia, que buscava consolidar-se enquanto classe dominante da sociedade francesa e o proletariado que ousava se colocar na arena política. As demais classes vão se colocando ora de um lado ora de outro, de acordo com os acontecimentos, mas por fim, acabam por alinharem-se junto à burguesia.

Lênin, ciente do acumulo teórico do marxismo até seus dias, expõe a parcialidade do Estado e a necessidade de, agora que o proletariado conseguira tomar o poder do Estado, constituir um novo tipo de Estado, o Proletário, ferramenta de poder da classe trabalhadora, que deveria fenecer para permitir a auto-organização dos trabalhadores. Ele escreve às vésperas de Outubro quando ainda era incerto o triunfo dos bolcheviques, mas se dedica a escrever sobre tarefas que deverão ser cumpridas após a revolução. Reúne em sua obra, tal como diz o subtítulo do livro, a doutrina do marxismo sobre o Estado, defendendo a visão de Marx e Engels e polemizando com os chamados revisionistas do marxismo.

Escrevendo sobre os acontecimentos franceses que ocorreram após a revolução de 1848, Marx, mostra os movimentos das classes em conflito, que buscam assenhorear-se do poder do Estado, sendo que a maior parte, sem buscar ameaçar a dominação de classe da burguesia. Daí Marx afirmar que a república francesa, surgida com a queda dos Orleáns, ser apenas o despotismo de uma classe, no caso a burguesia, sobre as demais. Lênin, observa que mesmo a república democrática, na sociedade burguesa, possui uma democracia "comprimida no quadro estreito da exploração capitalista e, por isso, sempre permanecerá, no fundo, a democracia de uma minoria, apenas para as classes possuidoras, apenas para os ricos" (LÊNIN, 2017, p.112).

Diante disso, mesmo quando ameaçada por Luís Napoleão, a reação da maior parte dos partidos, sejam republicanos, ou monarquistas, permaneciam inativos, uma vez que temiam que uma postura mais incisiva contra o chefe de governo acabasse por dar a oportunidade dos operários de abalarem os pilares do poder das classes proprietárias.

Enquanto isso, Napoleão ia arrebatando apoios entre a pequena burguesia, os camponeses, os funcionários públicos, a Igreja, enfim as camadas médias da nação, que 
acreditavam ter no novo homem forte um representante contra a burguesia industrial e rentista. Marx mostra que estas camadas sociais não poderiam estar mais enganadas. Já não estavam mais nos tempos do primeiro Napoleão, quando os ventos da república Jacobina haviam varrido a França e permitido que as camadas médias pudessem prosperar e ser um esteio à figura do imperador. O Estado feudal foi quebrado, para que se erigisse o Estado Burguês. Em 1851, embora apoiado nas camadas médias, o novo Napoleão não iria contrariar os interesses dos poderosos burgueses de França, que deixaram seus representantes no parlamento à própria sorte e entregaram o comando do país ao novo deposta, desde que este assegurasse a ordem necessárias aos seus negócios.

No entanto, era preciso impedir qualquer apoio para a classe revolucionária: os operários de Paris. Por isso as concessões às camadas médias, por isso a continuidade da farsa de Napoleão sobre toda a França. Esmagada a resistência operária, sem necessidade de manter as ilusões, Luís Napoleão se despe da figura de protetor dos camponeses e golpeia o parlamento, a república e os interesses de seus aliados de primeira hora. Aqui, fica claro que o funcionamento do Estado está afinado ao bom andamento da economia burguesa. Fica claro, com a leitura da obra, que o Estado não precisa estar sob o controle direto da burguesia para ter seu caráter de classe assegurado. Ele é intrinsecamente burguês.

Para Lênin, o Estado é o órgão de dominação de determinada classe sobre as demais, devendo, portanto, ser tomado pela classe revolucionária em luta e extinto. Afinal, o Estado, tal como Marx o apresenta no 18 Brumário e outros textos é uma força que está acima da sociedade e cada vez mais se aliena dela. A ressalva é que os oprimidos destroem esse Estado, essa ferramenta, para construir outra que esteja a serviço dos oprimidos e não dos exploradores.

O Estado e a Revolução é a defesa da extinção do Estado burguês de qualquer tipo pela revolução e sua substituição por um Semi-estado, um Estado que utilizará o poder repressor contra a burguesia, a ditadura do proletariado, no dizer de Lênin, a democracia mais completa que definhará até não se ter mais a necessidade de um aparelho repressor.

A experiência de 1848 estava diante dos bolcheviques para entenderem que a conciliação de classes, apenas disfarçava a dominação dos exploradores. A análise de Marx, de como a república parlamentar francesa, apenas reforçou a máquina do poder estatal mostrava como os operários deveriam atuar, uma vez que, mantido o Estado, tal 
como ele fora concebido pela burguesia, sucessivos governos, mesmo aliados ao proletariado ou surgidos do próprio proletariado, apenas administrariam os negócios dos verdadeiros senhores do Estado.

E qual a conclusão que Lênin chega ao estudar esse acúmulo, acrescentando-o com sua própria experiência? A conclusão de que "todas as revoluções anteriores aperfeiçoavam a máquina do Estado, mas é preciso destruí-la, quebra-la" (LÊNIN, 2017, p.51).

Reconhecer a existência da luta de classes, continua Lênin, não faz de você um marxista. Reconhecer tal fato é ainda permanecer dentro dos limites do pensamento e da política burguesa. O marxista precisa ir além e reconhecer a necessidade da ditadura do proletariado, da recusa total e completa da conciliação de classes e caminhar para a derrubada do Estado burguês e de suas cortinas de fumaça, cortinas essas que escondem que qualquer constituição do Estado burguês é apenas uma forma de ditadura da burguesia. Tal aconteceu na França e Marx capta no 18 Brumário, enquanto o poder não estava em risco, manteve-se o regime republicano e parlamentar, mas o levante dos operários levou ao abandono da fórmula democrática e a ascensão de um governo autoritário que conduziria a França pelas duas décadas seguintes.

É preciso ter em mente que Marx analisa uma revolução derrotada e a ascensão de um governo autoritário como última esperança de deter o poder político das classes dominantes. Lênin está liderando uma revolução vitoriosa, a qual se depara na prática com problemas e situações antes apenas enfrentadas a nível teórico. A reformulação é feita no calor do momento, tal como Marx escrevia quando se desenrolava os fatos e acontecimentos franceses. Luís Napoleão foi necessário para apresentar aos franceses, principalmente os das classes exploradas, que o Estado estava separado deles e servia a outros interesses. E isso apesar da vontade de Napoleão, o qual "gostaria de aparecer como o benfeitor patriarcal de todas as classes. Mas não pode dar a uma classe sem tirar de outra” (MARX, 1988, p.81). Sua missão era salvaguardar a ordem burguesa.

Mas como impedir que o Estado de novo tipo, surgido pelas mãos da revolução vitoriosa se torne também um aparelho de repressão que em vez de definhar e desaparecer, acabe por se fortalecer e impedir o surgimento da sociedade sem classes? Para Lênin era preciso que o Estado Operário atacasse em todas as frentes a sociedade burguesa: modificando as forças armadas e policiais, atuando contra a religião, que estupidifica o 
povo, contra a burocracia do Estado, uma vez "para suprimir o Estado é preciso transformar as funções do serviço do Estado em operações de controle e de registro tão simples que sejam acessíveis e realizáveis pela imensa maioria da população e, depois, por toda a população, sem exceção" (LÊNIN, 2017, p.102).

Diante do desfecho da experiência bolchevique, onde com a ascensão de Stalin, o Estado se fortaleceu e se tornou autocrático, cabe aqui lembrar da advertência escrita no 18 Brumário, "os homens fazem a sua própria história, mas não como querem; não a fazem sob circunstâncias de sua escolha e sim sob aquelas com que se defrontam diretamente, legadas e transmitidas do passado" (MARX, 1988, p.8). Entendendo a história como a expressão da luta de classes, Marx aponta que as condições de existência das classes em conflito devem ser consideradas, elas têm um peso enorme, o qual influência de forma determinante os atos e ações das classes.

O 18 Brumário traça o panorama das revoluções sociais do século XIX à espera das revoluções proletárias vitoriosas. O Estado e a Revolução parte de uma revolução vitoriosa que, a espera das demais revoluções, traça os caminhos para o comunismo, onde

“(...) desaparecerá toda a necessidade da violência sobre as pessoas em geral, da subordinação de um ser humano a outro, de uma parte da população a outra parte dela, porque as pessoas se habituarão a observar as condições elementares da convivência social sem violência e sem subordinação (LÊNIN, 2017, p.107).

Fica claro que Marx e Lênin, embora tenham escritos em situações tão diferentes, e separados por mais de meio século, apontem para a continuidade de uma concepção de Estado dentro da tradição marxista, que no momento em que Lênin escreve, está sendo questionada e revista. O reforço da mesma é uma mostra clara que o referencial teórico elaborado por Marx, não apenas sobre a economia capitalista, mas sobre a própria sociedade burguesa atuou como um manual de ação para os bolcheviques e fornece ainda elementos para entender a sociedade atual, onde a luta de classes brasileira, forçou um golpe em um governo que buscava conduzir reformas por dentro do capital e logo depois, elegeu um governo autoritário para assegurar a ordem burguesa, mesmo à custa da democracia, que vem sendo cada vez mais relativizada.

\section{A ofensiva burguesa no Brasil}

No Brasil, os governos petistas buscaram, por meio do Estado, reformar o sistema capitalista. No entanto, essas tentativas de, por dentro dos marcos do capital, 
diminuir as desigualdades sociais e promover direitos para os trabalhadores e os setores mais pobres da sociedade, apenas asseguram a permanência do sistema e de mitos como o que reafirmam que, sob o capitalismo, há oportunidades para todos. Essas políticas apenas mascaram a luta de classes, impedindo que os trabalhadores se reconheçam como classe, deixando de perceber que o econômico não pode ser separado do político (TRAGTEMBERG, 2005). Afinal, o objetivo do Capital é valorizar-se continuamente,

(...) em escala crescente e, por isso, ele desencadeia um processo de desenvolvimento das forças produtivas e da organização do processo de trabalho pelo trabalhador, de sorte a diminuir o mais possível as lacunas da jornada de trabalho. A divisão técnica do trabalho vem ao encontro dos interesses do capital, assim como o avanço técnico e tecnológico que simplifica o trabalho, fazendo com que não haja necessidade de qualificações específicas para realizá-lo. A intenção é a de aumentar a escala de produção diminuindo os custos, o que implica também em reduzir os gastos com a força de trabalho (OLIVEIRA, 2006, p. 114).

Daí a diminuição, não apenas dos salários, mas também dos investimentos, em saúde, educação e outros, pelo Estado aos trabalhadores. Estando o Estado organizado para defender os interesses do sistema capitalista, ele não pode implementar políticas públicas que escapem da lógica do Mercado, ficando estas, no marco de pequenas concessões que objetivam a perpetuação do sistema. Essas políticas, geralmente traduzidas em acesso a serviços e direitos básicos para a população trabalhadora, são, ao primeiro sinal de crise do capital, suspensas e/ou extintas, como observa Ianni, "em nome da 'modernização', 'produtividade', 'competitividade', 'qualidade total', 'lucratividade', 'entrada no primeiro mundo', são muitas as elites empenhadas em satanizar e mutilar as conquistas político-econômicas e socioculturais que se haviam realizado com base em projetos nacionais" (IANNI, 2004, p. 53). Diante da incapacidade do governo Dilma em aplicar, no ritmo desejado, o receituário neoliberal para a crise, investiu-se em um golpe que se utilizou das ferramentas do próprio regime democrático-liberal.

Nesse sentido, diferentemente das democracias liberais de outrora, que na maioria das vezes, foram destruídas quando das derrubadas de governos democráticos que se encontravam à sua frente, a democracia brasileira atual demonstrou dispor de mecanismos internos que lhe permitem eliminar um governo incômodo sem ter que conjuntamente eliminar a si mesma (DEMIER, 2017, p.16).

Atuando em conjunto com diversos grupos ideológicos da direita, além de vincularem a recessão econômica às políticas do governo petista, estimularam, por meio da publicidade de ações espalhafatosas da justiça, como a Operação Lava-Jato. O discurso 
anticorrupção projetou o sistema político como eminentemente corrupto (DEMIER, 2017), produzindo assim uma desqualificação da política.

\begin{abstract}
No lugar de explorar politicamente os erros, contradições e omissões do governo, a oposição preferiu apostar na desconstrução da presidente Dilma Roussef a partir do reforço de preconceitos e de tendências autoritárias presentes na sociedade brasileira. Mentiras, preconceitos (com destaque para a misoginia) e outras ações irracionais pontuaram as manifestações contra a expresidente e moldaram a rejeição ao seu governo. Limites jurídicos, éticos e civilizatórios foram violados (CASARA, 2020, p.30).
\end{abstract}

Foi a necessidade de recompor os ganhos da burguesia que levaram ao impedimento de Dilma Roussef, em 2016. Liderado por Temer, o governo seguinte deu início a uma profunda desregulamentação e precarização do trabalho com a supressão de direitos históricos dos trabalhadores por meio de reformas como a Trabalhista e o estabelecimento constitucional de um Teto de Gastos, que na prática limita por 20 anos as ações do governo federal (SILVA; BARBOSA, 2020). A insistência em constitucionalizar o Teto de Gastos e outras mudanças de cunho neoliberal faz parte da busca pelas classes dominantes de "tornar os regimes democráticos-liberais imunes (ou menos suscetíveis) às exigências populares" (DEMIER, 2017, p.36).

Por fim, em 2018, a eleição de Bolsonaro, conduziu ao Planalto, "um governo que defendia abertamente o neoliberalismo, com a defesa de privatizações, políticas de austeridade e uma agenda moral conservadora, que segue a tendência da direita em todo o mundo" (SILVA; BARBOSA, 2020, p.337). O presidente continua o movimento de limitar os "excessos" de democracia aplicando medidas como a independência do Banco Central, que, na prática, retira o Banco da influência do governo eleito e coloca sob a tutela do mercado. Em sintonia com a diminuição dos espaços para a expressão das demandas populares,

\title{
Bolsonarismos
}

Obscuro deputado ligado a pautas conservadoras, Bolsonaro viu sua popularidade crescer por meio de uma retórica agressiva contra os movimentos sociais e em apoio a uma maior repressão e violência policial como forma de combate à violência, "um político de perfil caricato que frequentava programas de variedades de qualidade duvidosa na televisão brasileira" (CASARA, 2020, p.32). Casara (2020) esclarece que em torna da sua candidatura uniram forças de matizes reacionárias, conservadoras, liberais e neoliberais. O bolsonarismo, movimento que se desenvolveu ao redor de Bolsonaro, pode ser definido 
(...) simplificadamente como a mais nova face da extrema-direita brasileira nas primeiras décadas do século XXI. Tendo como principais bases ideológicas o neoprotestantismo e a defesa do legado da ditadura militar, para o Bolsonarismo religiosidade e autoritarismo locupletam-se e reproduzem-se processando a linguagem da violência (em suas dimensões física e simbólica) como tática política (RIBEIRO, 2020, p.465).

Para Reis (2020), o bolsonarismo não é um fenômeno isolado, ao seguir um padrão internacional de reação a transformações sociais entendidas como ameaças a costumes, tradições e valores. Essa reação assume tons nacionalistas, ou melhor nacionalista de direita, nos mais diversos países,

(...) tem aparecido com grande força nos EUA (fenômeno Trump), na Europa Ocidental (Itália, França, Inglaterra), na Europa central (Hungria e Polônia), na Ásia (Filipinas e Índia), no mundo muçulmano (Irã e Egito) e na América Latina (Brasil, Chile, Colômbia). Trata-se de uma extrema-direita descomplexada, ativa e propositiva, de grande ativismo público, com frequentes incursões nas ruas, explorando as insuficiências e deficiências dos regimes democráticos, instrumentalizando-os quando convém, desfigurandoos "por dentro" e usando intensamente os mecanismos próprios da revolução digital (REIS, 2020, p. 3).

Dentro dessa perspectiva Reis (2020) lista como principais grupos do bolsonarismo: os aparelhos de segurança formais (polícias e forças armadas) e informais (milícias e a bancada da bala), que "agrupam-se em torno dos conceitos de ordem, de segurança e de defesa da pátria" (REIS, 2020, p.08). Outro grupo é constituído pelas igrejas evangélicas e os parlamentares a elas ligados, "aglutinadas em torno de pautas conservadoras relativas aos costumes e com importante expressão parlamentar” (REIS, 2020, p. 09). Esses dois grupos, os mais fiéis apoiadores de Bolsonaro demonstram que,

Em nome da disciplina, da hierarquia, da ordem, do nacionalismo e do moralismo, sua necropolítica ${ }^{1}$ tocou fundo em uma sociedade estruturalmente colonial-escravista e, três décadas depois da redemocratização, ainda seduzida por uma idílica representação da ditadura militar em que tudo funcionava a contento, não havia corrupção e nem desemprego e a criminalidade estava sob controle (RIBEIRO, 2020, p.473).

Além destes, Bolsonaro conseguiu articular apoio entre a burguesia, notadamente, “junto ao agronegócio (que não se confunde com o desmatamento desenfreado da Amazônia) e ao capital financeiro (o ultraliberalismo de Paulo Guedes)" (REIS, 2020, p.09), o terceiro grupo de sustentação do bolsonarismo. $\mathrm{O}$ acréscimo deste terceiro grupo por Reis (2020) em relação a Ribeiro (2020), apresenta um ponto importante para sustentação do governo, pois os interesses desses setores no cumprimento da agenda

\footnotetext{
${ }^{1}$ Conceito desenvolvido pelo filósofo camaronês Achile Mbembe, o qual Ribeiro (2020) utiliza como a centralidade da morte como ativo político da modernidade.
} 
neoliberal por parte do governo, acabaram "poupando-o de críticas, relativizando suas invectivas, protegendo-o de denúncias" (REIS, 2020, p.09).

Bolsonaro ainda acenou para uma parte da sociedade que desejava o fim da "velha política", expressão um tanto vaga, utilizada por think tanks de direita, para identificar as práticas de clientelismo e corrupção com a esquerda e seus partidos. O convite ao juiz Sérgio Moro para o Ministério da Justiça fez parte da estratégia para atrair esse público. Pode-se identificar ainda,

(...) o apoio de parcela significativa da classe média incomodada com a perda de privilégios econômicos e culturais, de intelectuais que se sentiram desprezados durante o governo petista (...) e, principalmente, de pessoas brancas das classes populares (segmento que costuma ser designado pejorativamente de White Trash) que acreditavam estar perdendo, em razão das políticas afirmativas adotadas pelo governo do Partido dos Trabalhadores, o privilégio que o racismo brasileiro thes assegurava (CASARA, 2020, p.32)

O discurso predominante da campanha, e mesmo após a posse, além da exaltação ao individualismo neoliberal e as loas ao Estado Mínimo, adotou um tom agressivo em relação a esquerda com seus membros e propostas "apontados como ameaças aos "valores da família', enquanto as tímidas políticas públicas de redução da desigualdade eram representadas como riscos às liberdades e à propriedade dos brasileiros. Investiu-se na mistificação. Reavivou-se o medo do comunismo" (CASARA, 2020, p.31).

Constituído por grupos com interesses tão díspares, o governo Bolsonaro tem se caracterizado por constantes desgastes ocasionados pela busca de predomínio deles na agenda do governo, no entanto,

Bolsonaro é levado, para atender prioritária, mas não exclusivamente aos
interesses do capital internacional e da burguesia associada, a entrar em
conflito com os segmentos da classe média que aspiram ao fim daquilo que
denominam "velha política" e com o movimento dos caminhoneiros, seus
apoiadores que se sentem traídos pela política de preços dos combustíveis que
atende aos interesses dos investidores internacionais (BOITO JR, 2020, p.117).

Somado a isso, a condução desastrosa do país durante a pandemia causada pelo COVID-19, pautada por negacionismo e anticientificismo, acabou por minar grande parte do apoio de Bolsonaro entre a população. Mas os grupos identificados por Reis (2020) ainda permanecem ao seu lado, muitas das vezes negando a má condução do país durante a pandemia ou mesmo a gravidade da doença. Talvez porque

(...)uma das especificidades do Bolsonarismo parece residir precisamente na adoção de uma ideologia de extrema-direita personificada, entretanto, não por um intelectual ou uma corrente de pensamento no sentido clássico dos termos, mas por alguém que encarna uma mescla de esoterismo e charlatanismo em tempos de redes sociais e de fake news (RIBEIRO, 2020, p.467). 
Outra característica do governo Bolsonaro, que não pode deixar de ser notada é a presença massiva de militares da reserva e da ativa em diversos cargos do executivo. Nenhum outro governo após a ditadura militar teve tantos militares em seu meio. Boa parte destes traz, como experiência de atuação com políticas públicas para civis, participação no contingente de tropas enviadas ao Haiti para coordenar a missão de paz da ONU no país. As tropas brasileiras utilizaram o país como campo de treinamento para intervenções urbanas (COGGIOLA, 2010), além de serem alvo de denúncias de opressão e de repressão ao povo haitiano (DURANS; SANTOS, 2016), que por diversas vezes manifestou-se exigindo o fim da Missão de Paz e a retirada dos soldados. É sintomático que os comandantes de tão controvertida ação militar, estejam em importantes postos do governo, inclusive soltando notas que desautorizam o congresso e o STF, em defesa de Bolsonaro.

Para Boito Jr.(2020), o governo dá sinais de incompetência organizativa, mas se defronta com uma esquerda fraca e desorganizada. Esquerda que, de acordo com Reis (2020), subestimou a força e o potencial de crescimento do bolsonarismo, sendo incapaz de constituir uma ampla frente do campo das esquerdas. E completa:

(...) cumpre às oposições, em particular às esquerdas, se rearticularem e incentivarem à resistência. Seja através do protesto (nenhuma ação ou decisão arbitrárias do Governo pode passar em branco), seja por meio da resistência (impedir, quando for possível, a concretização de medidas ou políticas governamentais) ou ainda, e melhor, por intermédio de elaboração de propostas alternativas (REIS, 2020, p.09-10).

Com a instalação, no Senado de uma Comissão Parlamentar de Inquérito sobre a Pandemia da COVID-19, que apresentou provas da inação de Bolsonaro frente à Pandemia e mesmo o envolvimento de ministros com irregularidades na compra de vacinas, milhares de brasileiros saíram às ruas em protesto por todo o país, mesmo diante do perigo de contaminação com o vírus.

Apesar de enfraquecido, com baixa popularidade, Bolsonaro continua à frente do governo, blindado por Artur Lira, presidente da Câmara dos Deputados, eleito com seu apoio, que se nega a dar andamento aos diversos pedidos de impeachment protocolados naquela casa legislativa, o presidente segue discursando para seus apoiadores fiéis, desqualificando a democracia e reforçando a narrativa messiânica que caracterizou a sua campanha eleitoral, junto com os disparos em massa de notícias falsas pelas redes sociais.

\section{Conclusão}

Cadernos GPOSSHE On-line, Fortaleza, v. 4, n. Único, 2021. 
Tal como na França de Napoleão III, as classes médias, diante do temor de transformações radicais na sociedade, juntam-se à figura de um homem forte, não pertencente ao sistema, como forma de preservar suas posições dentro do esquema de classes brasileiro. Mas tal opção apenas a aproximou ainda mais das classes baixas, uma vez que as políticas econômicas de Bolsonaro e Paulo Guedes atendem apenas aos setores do agronegócio e do sistema financeiro que aderiram ao seu governo e empobrecem a todas as classes não burguesas.

Apesar do desgaste, Bolsonaro ainda possui uma base expressiva nos grupos que constituíram o bolsonarismo desde as primeiras horas. Apesar dos seus ataques aos movimentos sociais e às organizações de classe dos trabalhadores, como os sindicatos e as centrais sindicais, a resistência às suas investidas é encabeçada principalmente por esses setores, que encabeçaram os protestos por Fora Bolsonaro durante a pandemia.

A anulação da condenação do ex-presidente Lula, o que lhe devolveu seus direitos políticos acrescentou mais um ingrediente à política brasileira, com a possibilidade de sua candidatura nas eleições de 2022. No entanto, a situação ainda se encontra em aberto. O processo de impeachment avança no congresso, onde o presidente ainda conta com uma base considerável. Apesar das bravatas, Bolsonaro parece não ter apoio sólido para desferir um golpe de Estado. Boa parte da burguesia e da imprensa não apoiaria essa aventura e a derrota de seus aliados nos Estados Unidos e nos países vizinhos, além da gravidade da situação da pandemia do COVID-19, Bolsonaro internacionalmente. Este ainda aposta que o fim das medidas de isolamento impostas para conter a pandemia e uma certa recuperação econômica ainda podem resgatar seus índices de popularidade e pavimentar o caminho para a reeleição. No entanto, não importa o que digam os neoliberais no governo, de acordo com Blyth (2017), as políticas de austeridade, longe de beneficiar a economia, possuem caráter recessivos duríssimos, além de aprofundarem as desigualdades sociais ao piorar as condições de vida da maioria dos brasileiros.. 


\section{Referências}

ANTUNES, Ricardo; PINTO, Geraldo Augusto. A fábrica da educação: da flexibilização taylorista à flexibilização toyotista. São Paulo: Editora Cortez, 2017.

BLYTH, Mark. Austeridade: a história de uma ideia perigosa. São Paulo: Autonomia Literária, 2017.

BOITO JR, Armando. Por que caracterizar o bolsonarismo como neofascismo? Revista Crítica Marxista, n.50, p. 111-119, 2020.

CASARA, Rubens R R. Bolsonaro: o mito e o sintoma. São Paulo: Editora Contracorrente, 2020.

CHAUÍ, Marilena. Escritos sobre a universidade. São Paulo: Editora Unesp, 2001.

CHAUÍ, Marilena. O ser humano é um ser social. São Paulo: Editora WMF Martins Fontes, 2013.

COGGIOLA, Osvaldo. Haiti: terremoto, colonização e resistência. O Olho da História, n. 14, Salvador (BA), junho de 2010.

DARDOT, Pierre; LAVAL, Christian. A Nova Razão do mundo: ensaio sobre a sociedade neoliberal. São Paulo: Boitempo, 2016.

DEMIER, Felipe. Depois do golpe: a dialética da democracia blindada no Brasil. Rio de Janeiro: Mauad X, 2017.

DOMINGUES, Ivan. O trabalho e a técnica. São Paulo: Editora WMF Martins Fontes, 2016.

DURANS, Cláudia Alves; SANTOS, Rosenverck Estrela. HAITI: significado histórico, realidade e perspectivas. Revista de Políticas Públicas, pp. 127-133, São Luís, 2016

ENGELS, Friedrich. Sobre a importância da luta política. In: Trabalhadores, uni-vos: Antologia política da I Internacional. Org.: Marcello Musto. São Paulo: Boitempo, 2014

IANNI, Octavio. Capitalismo, violência e terrorismo. Rio de janeiro: Civilização Brasileira, 2004.

LÊNIN, Vladímir Ilitch. O Estado e a Revolução: a doutrina do marxismo sobre o Estado e as tarefas do proletariado na revolução. São Paulo: Boitempo Editorial, 2017

LESSA, Sérgio; TONET, Ivo. Introdução à filosofia de Marx. São Paulo: Expressão Popular, 2011.

MARTINS, José Antônio. Filosofia Política. São Paulo: Editora WMF Martins Fontes, 2015.

MARX, Karl. O 18 Brumário de Luís Bonaparte. In: Manuscritos econômicos filosóficos e outros textos escolhidos - Volume II. Trad. José Carlos Bruni. São Paulo: Editora Nova Cultural, 1988. 
MARX, Karl. Miséria da filosofia. São Paulo: Martin Claret, 2008

MARX, Karl. Sobre a comuna. In: Trabalhadores, uni-vos: Antologia política da I Internacional. Org.: Marcello Musto. São Paulo: Boitempo, 2014

MARX, Karl; ENGELS, Friedrich. A Ideologia Alemã. Trad. Frank Müller. Sumaré/SP: Martin Claret, 2006

MARX, Karl; ENGELS Friedrich. Manifesto do Partido Comunista. São Paulo: Edipro, 2015.

MASCARO, Alysson Leandro. A crítica do Estado e do direito: a forma política e a forma jurídica. In: Curso livre Marx-Engels: a criação destruidora. Org. José Paulo Netto. São Paulo: Boitempo, Carta Maior, 2015

OLIVEIRA, Lilian Haffner da Rocha. A teoria do valor em Marx e a organização do trabalho coletivo na escola: elementos para uma reflexão crítica. In: A teoria do valor em Marx e a educação. Org. Vítor Henrique Paro. São Paulo: Cortez Editora, 2006

REIS, Daniel Aarão. Notas para compreensão do Bolsonarismo. Estudos IberoAmericanos, Porto Alegre, v. 46, n. 1, p. 1-11, jan.-abr. 2020

RIBEIRO, Guilherme. Entre armas e púlpitos: a necropolítica do Bolsonarismo. Revista Continentes (UFRRJ), ano 9, n. 16, p. 463-485, 2020.

SANDEL, Michael J. O que o dinheiro não compra: os limites morais do mercado. Rio de Janeiro: Civilização Brasileira, 2012.

SILVA, Christian Luiz da; BASSI, Nadia Solange Schmidt. Políticas públicas e desenvolvimento local. In: Políticas Públicas e desenvolvimento local: instrumentos e proposições de análise para o Brasil. Christian Luiz da Silva (org). Petrópolis, RJ: Vozes, 2012.

SILVA, Wagner Pires da; BARBOSA, Erlene Pereira. Austeridade e neoliberalismo no Brasil pós-golpe. Rev. Sítio Novo, Palmas, v. 4 n. 3 p. 336-347 jul./set. 2020

TRAGTENBERG, Maurício. Administração, poder e ideologia. São Paulo: Editora UNESP, 2005

Recebido em: 6/8/2021

Aceito em: 30/8/2021

Publicado online em: $3 / 9 / 2021$

Cadernos GPOSSHE On-line, Fortaleza, v. 4, n. Único, 2021. 